\title{
STRENGTHS, WEAKNESSES, OPPORTUNITIES AND THREATS (SWOT) ANALYSES FOR MULTIPLE EXTENSION SERVICES IN THE HIGH VALUE CROP PROGRAMME: INSIGHT FOR PLURALISTIC EXTENSION POLICY
}

\author{
Kau, J. S. ${ }^{1}$, Mahlangu, S. A. ${ }^{2}$ and Maku, M. ${ }^{3}$ \\ Correspondence author: J. S. Kau. E-mail: Kauj@arc.agric.za
}

\begin{abstract}
Following an extensive consultative process that looked into the challenges underpinning the public extension services in South Africa in 2016, the government introduced a new policy that advocates for a pluralistic approach when rendering extension services. Using the High Value Crop (HVC) Programme in OR Tambo as a case study, the objective of this paper is to carry out the Strength, Weaknesses, Opportunity and Threats (SWOT) analyses in order to generate insights into the important policy directives to be considered when implementing the new policy. Results show that participation of multiple extension agencies in the HVC served as a strength for the project. In terms of weaknesses, the issue of failure to implement partnership agreements at a project level and lack of coordination of services rendered were viewed as challenges. Furthermore, pluralistic extension services carry opportunities for smallholder farmers. For public extension officers to play a role of coordination in a pluralistic extension service, more resources (personnel numbers and funding) need to be mobilised. In order to ensure project sustainability, different extension agencies need to develop a common exit strategy.
\end{abstract}

Keywords: High value crops, Opportunities, Pluralistic model, Strengths, Threats, Weaknesses

\section{INTRODUCTION}

The Strength, Weaknesses, Opportunity and Threats (SWOT) analyses is an important tool used widely in business and academic circles to analyse the strategic position of organisations, programmes and projects (Helms \& Nixon, 2010; Von Kodolitsch et al, 2015). In the work of Helms and Nixon (2010), where they reviewed the application of SWOT analyses in various fields of business, it was discovered during a 10-year period (2000 to 2010) that more than 32 peer-reviewed published articles used SWOT analyses as a tool for analysis. In the agricultural sector, the SWOT analyses is used to assess the strategic position of projects. In India, the tool was used to analyse the agricultural sector in terms of its capacity to meet future food security requirements (Padaria et al, 2013). The Agriculture Finance Support Facility division of the World Bank used SWOT analyses, among other tools, to review the Bank's past agricultural lending performance and to predict future performance (World Bank, 2015). In addition, closely related to the analyses in this paper, is the study conducted by the Food and Agriculture Organisation (FAO) in Zimbabwe. It used this tool to analyse the status of a pluralistic

\footnotetext{
1 Agricultural Economist, Agricultural Research Council of South Africa, Pretoria, South Africa, e-mail: kauj@arc.agric.za

2 Agricultural Economist, Agricultural Research Council of South Africa, Pretoria, South Africa, e-mail: mahlangusa@arc.agric.za

${ }^{3}$ MSc Student, Department of Agricultural Economics, Extension, University of Fort Hare, Fort Hare, South Africa, e-mail: mbonisimaku@gmail.com
} 
agricultural extension system (FAO, 2002). Oladele et al (2009) also used SWOT analyses to study the performance of extension systems of selected countries in the Southern African region.

The objective in this paper is to employ SWOT analyses to analyse the working relationship amongst different extension agencies working in the High Value Crop (HVC) production programme of the Agricultural Research Council (ARC), with a view of generating insight that will guide the implementation of a new policy in South Africa on pluralistic extension services. The HVC is an agricultural programme for the cultivation of fruit trees, herbs and vegetables through conservation practices. The Institute for Tropical and Sub-tropical Crops of the ARC (ARC-ITSC), together with a Non-Government Organisation (NGO), the Is' Baya Development Trust, established the HVC in 1999. The main goal for the ARC is to introduce high value crops (sub-tropical, deciduous, industrial and certain vegetable crops) through Conservation Agriculture (CA) in order to address various socio-economic challenges faced by communities in the OR Tambo district municipality. The seven local municipalities in OR Tambo include Mbashe, Mnguma, Nyandeni, King Sabata Dalindyebo (KSD), Port St Johns (PSJ), Ingquza Hill, and Mhlontlo. The main objectives for the HVC were skills transfer, food security and income generation. While the ARC and Is' Baya Development Trust are the main drivers of the HVC, by default, there are other extension agencies providing extension services in the HVC. These include the District Office for the Provincial Department of Agriculture in OR Tambo, the Lima Rural Development Foundation, and Potato South Africa.

\subsection{Issues around multiple extension services and pluralistic extension model}

According to the International Food Policy Research Institute (IFPRI, 2009), in the 1990's and the 2000's, several developing countries such as Ethiopia, Ghana, Benin, Mali, Mozambique, Nigeria, and Zambia have transformed their traditional extension services to one that is demand-driven and of a pluralistic nature. As observed by Rivera and Alex (2004:41), "Extension is conceptually and in practice more than it used to be, as its function and tasks are increasingly assumed by multiple organisations". In South Africa, in the aftermath of market liberalisation, there has been emergence of multiple extension services (Kirsten, Stander \& Haankuku, 2010), yet to date, there has been limited research focussing on the effectiveness of these models. Since 1996, there has been different forms of partnerships for agricultural extension in South Africa.

In 1997, an initiative by the National Wool Growers Association of South Africa, aimed at transferring agricultural skills to emerging farmers, saw more than five stakeholders working together (De Beer, 2009). The stakeholders comprised of government departments, international NGOs, agricultural commodity groups, farmer trust organisations, and research organisations (De Beer, 2009). Other similar multiple extension services partnerships include those of the South African Sugar Industry (Eweg, 2009), the North West Cooperative (NWK) (Janse Van Vuuren, 2009), the Centre for Rural Community Empowerment of the University of Limpopo (Letsoalo \& Mollel, 2009), and the Mngcunube Development Trust for livestock improvement scheme (Jordaan, Sissons \& Blaker, 2009). In the work of Kirsten et al (2010) and Liebenberg (2015), it is highlighted that in the aftermath of democracy in South Africa, several multinational companies dealing with seed, fertilizer and agro-chemicals, as well as machinery have formed partnerships with local companies and that they have in-house extension services for small-scale farmers. In other neighbouring countries such as Malawi and 
Mozambique (Republic of Mozambique, 2007), participation of multiple agricultural extension agencies or pluralistic extension services have long been adopted at a national level.

In Mozambique, there is no appreciation for the role played by other private extension organisations (Gemo, Stevens \& Chilonda, 2013). In general, pluralistic extension services in Africa seem to be a new concept, with several authors pointing out that it started in the early 1990's (Catling, 2008; IFPRI, 2009). A number of case studies presented during the $43^{\text {rd }}$ conference of the South African Society of Agricultural Extension (SASAE) did not provide details of interactions among various extension agencies at project level. However, the 2016 National Policy on Extension and Advisory Services for South Africa provided profound directives regarding the new approach to extension and advisory services (Department of Agriculture, Forestry and Fisheries (DAFF), 2016). In terms of the new policy, extension and advisory services shall be provided through a pluralistic approach (DAFF, 2016). The implications are that different agricultural practitioners will have to work together in providing extension and advisory services in a more coordinated manner. In exploring different models for implementing the new policy, practical examples derived from existing projects are necessary. The HVC, due to the involvement of multiple extension agencies working in smallscale farming, bears strategic policy directives for South Africa. In South Africa, small-scale farmers received poor extension services in the past (Duvel, 2003). The HVC is also established in one of the poorest regions in South Africa (Altman, Hart \& Jacobs, 2009). Thus, this paper adds to the body of knowledge from two perspectives, namely for future planning for implementation of the new policy, and for providing a baseline for future research.

\section{METHODOLOGY}

The data used in this paper was derived from economic impact studies conducted in 2012 and 2017, as well as online surveys conducted in 2018. In 2012, 90 households were interviewed, whereas in $2017,58 \%$ of those covered during 2012 were repeated. In 2017, only three municipalities that constituted the highest proportion (58\%) of households sampled in 2012 were covered. In 2017 and 2018, questionnaires were e-mailed to four extension agencies participating in the HVC. To obtain a representative sample, a multi-stage sampling method was employed. Firstly, the seven local municipalities within the OR Tambo district where HVC had already been introduced were purposively selected. The second stage involved simple random sampling to select two households from 45 villages in the seven municipalities. In order to ensure that a balanced mix of farm sizes were included in the sample, stratified sampling was employed (Yount, 2006).

Collection of data involved seven distinctive methods, namely focus group discussions, field interviews using semi-structured questionnaires, e-mailed questionnaires, telephonic interviews, internet searches, transact walks, and review of organisations' records. Due to high levels of illiteracy amongst farmers and to obtain information relating to SWOT analyses, a combination of direct and proxy questions were asked. For extension agencies, direct questions relating to SWOT analyses were asked. Collected data were cleaned, verified and coded so that it could be handled with ease in a Microsoft Excel spreadsheet. Using simple statistical functions such as frequencies, correlation, averages and count-if functions, descriptive statistics were performed using Microsoft Excel 2016. The results of the SWOT analyses are based on mixed methods. 


\section{RESULTS AND DISCUSSION}

An overview of different extension models applied in the HVC is initially provided. This is followed by the results for the SWOT analyses.

\subsection{Extension model applied by the ARC and Is' Baya Development Trust}

In 1999, the ARC-ITSC conducted the feasibility study in collaboration with the Centre for International Cooperation in Agricultural Research for Development (CIRAD) which is an NGO. For the transfer of technology, the ARC-ITSC collaborated with another NGO, the Is' Baya Development Trust. The NGO has its own in-house extension services. In terms of extension capacity for the OR Tambo district municipality, there was one field manager responsible for 49 villages. The field manager had technical staff in the villages, namely the village monitors. Their important role was to monitor progress of the projects and where problems are encountered, they either resolve them or refer the matters to the ARC. The monitors resided in the village and were known to local farmers. According to Jadallah, Baker and Mohd (2011), development programmes worldwide have recognised that local participation is the key to sustainable transfer and long-term adoption of new technologies and approaches.

Another strategy by Is' Baya involved the recognition for certain farmers for the good progress made on their projects (e.g. commercialisation of farm produce). These farmers were referred to as lead farmers. Lead farmers were used as referral cases, for under-performing farmers. Prior to farmers working independently, 13 demonstration projects were established in various parts of OR Tambo with participating farmers. Farmers were then encouraged to start small projects in the backyard. As part of CA principles, intercropping of fruit crops with herbs, industrial crops and vegetables was encouraged. Farmers were not prohibited from cultivating other crops, including those promoted by third party extension agencies. Usage of inorganic fertilizers were however discouraged. Instead, farmers were encouraged to use compost and kraal manure. To retain soil moisture, farmers were advised to apply mulching. For promoting entrepreneurship, farmers were mobilised into a cooperative. The ARC-ITSC developed a seasonal calendar for the farmers, which assisted in guiding the farmers about different schedules for farming activities. Farmers were also encouraged to record information for farm sales and income. Certified fruit trees were sold at a 50\% discount. Farmers used their own money to pay for the trees. According to FAO (2016), in working with smallholder farmers, accountability is strengthened when farmers become co-owners of the services they receive and that they need to pay for some of the services. It further advised governments to put in place innovative financing mechanisms to help farmers that cannot afford extension services.

For expansion, other farmers secured additional land through permission to occupy arrangements. Establishing the projects at the backyard ensured provision of labour by household members. Another institute, the ARC Infruitec-Nietvoorbij, was also pulled into the project. ARC Infruitec-Nietvoorbij trained farmers on tree pruning and fruit processing. Through transact walks on the farms, it was discovered that farmers were starting to use more environment-friendly methods. These methods included usage of sunlight, dishwashing for controlling insects, application of mulching for conservation of moisture, and application of organic compost for soil fertility. As at the time of survey, the ARC-ITSC and Is' Baya had assisted in linking farmers with certain markets from surrounding towns. There were no supply contracts in place. 
As part of the exit strategy, six strategies were developed. The first strategy involved training young people (the village monitors) on various aspects of business management. Their role included sourcing farm inputs and access to markets, as well as monitoring and evaluation of projects. The second strategy involved the establishment of primary cooperatives which coordinated the agro-processing activity with the long term plan of establishing a secondary coop that will serve to coordinate accessibility to tertiary services such as markets, credit, information, and new technologies. The third strategy involved the development of the Community Development Association (CDA), a legal body charged with the mandate of representing the community at the local government. The fourth strategy was to develop the village agricultural production plans, which will serve to coordinate different types of crops cultivated in various villages and also coordinate supply of produce to the markets. The fifth strategy revolved around training of local public extension officers on fruit tree cultivation and commercialisation, as this will ensure ongoing support. The sixth and final strategy involved farm level infrastructure development such as pack-house, irrigation and fencing, with funding sourced from some of the programmes of the Department of Agriculture, such as the Comprehensive Agricultural Support Programme (CASP). These strategies are said to be long term.

\subsection{The extension models by other agencies}

\subsubsection{Extension model by the public extension officers}

According to the farmers (58 out of 90 interviewed), in 1999, when the HVC was introduced, the extension officers from the district office of the Provincial Department of Agriculture (i.e. public extension officers) were already working in OR Tambo. The nature of extension services rendered by the public extension officers involved transfer of skills and promotion of crops (cabbage, tomato, maize and spinach) which were only addressing the food security needs of certain farmers (40 out of 90 interviewed). Furthermore, 50 farmers out of 90 interviewed complained that they would have preferred a training on how to market and commercialise their produce.

The public extension officers did not have a programme in place to address challenges relating to commercialisation of the produce. During both the 2012 and 2017 surveys, the maize commodity featured predominantly among farmers interviewed. Public extension officers trained farmers on high yielding maize varieties, selection of good quality seed for replanting in the next season, and encouraged farmers to sell the maize seed to other villagers, either as seed or for consumption purposes. According to farmers, public extension officers did not introduce a programme relating to accessibility of formal markets. In 2012, maize was found to be occupying a larger proportion of land cultivated, while in 2017 , the same observation was made, yet compared to other commodities, maize yielded low income. In addition, 20 farmers out of 90 interviewed stated that extension officers visited their projects only twice in a year, whereas others said that they sometimes visited.

Upon assessing the information provided by farmers in the HVC, the model appeared as a topdown approach. Van Niekerk et al (2011) made similar findings regarding the top-down approach of public extension services in the Eastern Cape Province of South Africa. In the new policy, except for commitment made towards capacity building for public extension officers, the issue of top-down approach is not addressed adequately. Given the history of public 
extension services and the current financial constraints underpinning South Africa's fiscus, reclaiming confidence from the agricultural sector is important. In 2017, it was stated that several departments, including the Department of Agriculture, would face budgetary cuts (National Treasury, 2017), and this may further impact negatively on the services of public extension officers. The office of public extension in OR Tambo did not have a clear exit strategy. When asked about the exit strategy, they were of the opinion that production scientists and researchers situated at the Döhne research station would always be available to assist farmers. Regarding market access, it was stated that Kei fresh produce market was available to the farmers. Provision of agricultural bursaries to the youth was said to be a strategy for ensuring that youth will succeed their parents in the HVC.

\subsubsection{Extension services by Potato SA}

Results indicated that $52 \%$ of households interviewed received extension services from Potato SA and about 50\% received services from both Lima NGO and Potato SA. As evidenced from the 2012 survey results, Potato SA had only reached households in four municipalities out of seven considered in the study, namely Inguza Hill, PSJ, Nyandeni, and KSD. The objective of Potato SA is to assist emerging black potato producers to participate in mainstream commercial agriculture (Potato SA, 2018). According to farmers, Potato SA started working in OR Tambo in 2006. However, a report by Potato SA (2006) titled "Half yearly report for activities of the transformation programme" shows that the association had already started conducting trials in various parts of the Eastern Cape Province as early as 2002. The extension model for Potato SA entailed using its private extension officers to organise farmer day meetings where farmers are trained on various cultivation practices. Potato SA provided certified potato planting material at no cost and issued small unsecured production loans (Potato SA, 2006; Potato SA, 2014; Potato SA, 2015). Farmers were trained to sell potatoes as a raw product and as a seedling to new-entrant farmers. In 2002, Potato SA formed a partnership with OR Tambo Farmers' Association (ORTAFA), which is an affiliate of National African Farmers' Union (NAFU).

A steering committee comprising of Potato SA, Provincial Department of Agriculture, Kei Fresh Produce Market, LIMA, ORTAFA, and OR Tambo district municipality was set up (Potato SA, 2006). Farmers (54\% of respondents) mentioned that Potato SA extension officers' visits are on an ad hoc basis. For exit strategy, Potato SA devised two plans. The first one involved recruitment of youth, whereas the second one was about training farmers on viable methods for production of potato seeds. The seeds could be sold to other new entry farmers within OR Tambo, ensuring the organic expansion of the project within the district.

\subsubsection{Extension services by Lima NGO}

Farmers in seven local municipalities indicated that Lima NGO has been working with them since 2006. This was further supported by Lima stating that it was servicing about 1360 farmers from 130 villages across the municipality. The objectives of Lima NGO is somehow similar to that of the ARC, but the difference is on the extension model applied.

In the questionnaire completed by Lima NGO, the objectives of the NGO are stated as follows: to develop a smallholder farmer into a sustainable business, and to equip them with the knowledge that is needed to run a successful business. Since they are co-funded by Jobs Fund, they measure the success of the programme through the generation of farmer jobs (when a farmer meets a proxy turnover). 
According to Lima NGO, a proxy turnover is when a farmer realises an annual turnover of R32 000. The NGO used its in-house extension officers to render extension services. The structure for the personnel in the field is as follows: one full-time agricultural facilitator who is responsible for the efficient running of the site and is supported by an assistant facilitator. At the lower level, there is a zone manager. He assists with all aspects of the site facilitation and is involved with farmer training. Through liaison with local tribal authorities, trials and farmer day meetings are organised. The important lessons imparted included the construction of a small-scale nursery and homemade compost. Through transact walks on the projects, it was discovered that the process for building compost was intensive. It involved having to dig a pit, almost six feet long, where various layers of debris and rubble were put on top of each other and grey water was poured into the pit to stimulate decomposition. The rubble comprised of grass and leaves, rusted tins and metal, and bones. The NGO provided seedlings for vegetable crops (e.g. spinach and tomato). According to $40 \%$ of the farmers interviewed, Lima extension officers visited projects three times in a year. Strategies for ensuring that farmers remain independent in the long term relied heavily on skills' transfer, recruitment of youth, and provision of farm credit. There was a plan to phase out the old culture of providing free services and handouts to farmers, with farmers trained to produce their own vegetable seedlings.

\subsection{SWOT analyses}

Table 1 provides a summary of the different attributes of SWOT analysis, which are discussed separately in the following sections.

Table 1: Summary for the SWOT analyses relating to multiple extension services

\begin{tabular}{|c|c|}
\hline Strengths & Weaknesses \\
\hline $\begin{array}{l}\text { - Free services and products offered by } \\
\text { different agencies }\end{array}$ & $\begin{array}{l}\text { - Lack of coordination for multiple extension } \\
\text { services }\end{array}$ \\
\hline - Variety of commodities cultivated & $\begin{array}{l}\text { - Lack of implementation for existing } \\
\text { partnerships at project level }\end{array}$ \\
\hline $\begin{array}{l}\text { - Inclusive participation and farmer } \\
\text { involvement }\end{array}$ & $\begin{array}{l}\text { - Varying degree of crop intensity and } \\
\text { uniformity }\end{array}$ \\
\hline - Role of the ARC as a driving agent & - Poor participation of youth \\
\hline - Complementary services & \multirow{3}{*}{$\begin{array}{l}\text { - No joint and common exit strategy among } \\
\text { extension agencies }\end{array}$} \\
\hline - Design of the farm enterprise & \\
\hline - Diverse nature of extension models applied & \\
\hline Opportunities & Threats \\
\hline $\begin{array}{l}\text { High demand for the crops promoted by } \\
\text { various extension agencies }\end{array}$ & - Lack of resources, funding in particular \\
\hline - Favourable agrological conditions & - $\quad$ Poor \\
\hline - Media coverage and exposure & - Conflict and politics \\
\hline $\begin{array}{lllll}\text { - } & \begin{array}{l}\text { Poverty and high } \\
\text { underdevelopment }\end{array} & \text { level of } \\
\end{array}$ & - Aging farmer population \\
\hline $\begin{array}{l}\text { - High accessibility to social grants by } \\
\text { participants }\end{array}$ & $\begin{array}{l}\text { - Dwindling and waning financial support for } \\
\text { agencies }\end{array}$ \\
\hline $\begin{array}{l}\text { - Low competition for commodities } \\
\text { cultivated }\end{array}$ & $\begin{array}{l}\text { - Conflicts for claiming undue credit for the } \\
\text { work delivered by other agencies }\end{array}$ \\
\hline
\end{tabular}


S. Afr. J. Agric. Ext.

Vol. 47 No. 3, 2019: 32 - 45

http://dx.doi.org/10.17159/2413-3221/2019/v47n3a513
Kau, Mahlangu \&

Maku

(License: CC BY 4.0)

\subsubsection{Strengths}

Results from the survey regarding farmers' opinions for the participation of multi extension agencies shows that $45 \%$ liked receiving services and products for free. The second important factor was about the variety of commodities promoted by the different agencies (cited by $23 \%$ ), whereas farmer involvement in planning and implementation was cited by $18 \%$. The results show that farmers adopted crops promoted by the different extension agencies. A high proportion $(87 \%)$ had adopted the crops and CA practices promoted by the ARC-ITSC, whereas $100 \%$ had adopted fruit trees, though at varying levels of intensity. Furthermore, 36\% had adopted maize, $31 \%$ adopted cabbage and spinach, and $36 \%$ adopted potatoes. CA was also partly practised by LIMA NGO, yet this was delivered as piece meal without a formalised programme. This finding resonates well with the provisions of the new policy. Section 5.1 of the policy talks to the need for a climate smart agriculture. In the HVC, women were well represented as they constituted $37 \%$ of the sample.

One of the strengths regarding the involvement of multiple extension agencies related to the involvement of the ARC-ITSC as a driving agent. The ARC did not see the involvement of third party extension agencies as a threat, which is probably because it is state owned. As a result of the research capacity built over many years (since 1926), there is significant Research and Development (R\&D) capacity in the ARC-ITSC. This includes suitable cultivars for OR Tambo region, experienced researchers, and/or business networks. Other strengths included striking a collaboration with an NGO (the Is' Baya) that was familiar with agricultural development in OR Tambo, conducting the feasibility study, the design of the farm enterprises, and the extension model applied. In the new paradigm of agricultural development, extension services are market-driven and agribusiness orientated (FAO, 2001). Creation of market linkages, although informal, was another strength. The role of government (through the ARCITSC) becomes even more important in situations where there is market failure (Anderson \& Feder, 2003) and information asymmetry (Rivera \& Alex, 2004). The extension models applied by other agencies provided another strength in the HVC. This was in terms of provision of vegetable seedlings (free of charge), farm equipment and infrastructure.

The design of the farm enterprise, which included intercropping of fruit trees with field crops and vegetables, created an enabling environment for participation of multiple extension agencies. Although it could be seen as an act of piracy, some of the third party extension agencies used the HVC as a referral case for success in order to impress donor agencies. For example, in Colosa village, public extension officers invited the Member of Executive Council (MEC) of agriculture to come and see the projects. The MEC donated 600 bags of potato seedlings and farm implements. The LIMA NGO and the district office of extension officers in OR Tambo did however mention that some extension agencies has a tendency of claiming credit for the work delivered by others, and that this behaviour seldom caused conflicts. Another important point is that the HVC's ability to attract a high number of extension agencies has to do with the long-term nature of investments. For example, fruit trees, once planted, can continue to yield fruit for up to 25 years. This alone is enough motivation and incentive for various extension agencies to work in the HVC. The diverse extension services rendered were largely complementary to the goals of the ARC-ITSC. 
S. Afr. J. Agric. Ext.

Vol. 47 No. 3, 2019: 32 - 45

http://dx.doi.org/10.17159/2413-3221/2019/v47n3a513
Kau, Mahlangu \&

Maku

(License: CC BY 4.0)

\subsubsection{Weaknesses}

Failure of various extension agencies to render a joint farmer training programme was mentioned by $72 \%$ of the farmers as an important weakness. Extension agencies mentioned the lack of implementation for existing partnerships at project level as one of the weaknesses. It was observed in all 90 visited households, that the degree of crop intensity for the commodities promoted by the ARC (i.e. fruit crops, herbs and industrial crops) and the cycles of production were not uniform and there was no coordination for these activities. Combined with the fact that there was a drive to mobilise HVC farmers into a cooperative, a lack of coordination in the aforementioned area would result in a situation where certain farmers fail to meet quotas for the required crop volumes. Fruits for processing were supplied voluntarily and there was no supply quota in place yet. As a result, the income derived from cooperative activities was small. For the 2011/2012 farming season, a group of 12 farmers generated an annual income of R1000 for sales of jam. Some farmers, due to small plot sizes (1.5 ha on average), only cultivated a few fruit trees mainly for home consumption. High farm income was associated with large plot size and a high number of fruit trees, however, among different extension agencies, there was no plan for increasing the plot size.

The steering committee established by Potato SA in 2002 in OR Tambo municipality, aimed at coordinating the activities of different extension agencies, did not yield the desired results. This is because the services at the project level remained fragmented. Even when public extension officers were part of the steering committee, they did not play the coordination role. In South Africa, the transformation and restructuring programme put in place in the aftermath of democracy did not necessarily address the challenges inherent in the public extension sector (Ngomane, Thomson \& Radhakrishna, 2002). According to Duvel (2003), the structural transformations put in place by the Department of Agriculture in the aftermath of democracy, had only served to cause bureaucracy and leadership vacuum, instead of capacitating extension services. In 2005, the ratio of extension staff to commercial farmers was 1:21 and 1:878 to subsistence (Programme to Support Pro-poor Policy Development in South Africa (PSPPD), 2011). The few extension officers available were said to be performing other services that had nothing to do with agriculture (Last, 2006). There is also acknowledgement on part of the government that extension officers from Provincial Departments of Agriculture are not well capacitated (DAFF, 2016). Another weakness related to the lack of coordination is the application of fertilizers. Certain households (49\% of the 90 interviewed) applied fertilizers, yet this was against the directives of the ARC-ITSC. The ARC-ITSC instead promoted the usage of compost.

Farmers received fertilizers from public extension officers and from Potato SA. Interestingly, fertilizer application was found to have boosted the level of farm income among potato producers. Other aspects on the lack of coordination found at an organisational level involved the existence of different forms of agreements for partnerships (Potato SA, 2006), yet at project level, there was no formalised interaction. Another challenge relates to lack of communication from within organisations. For instance, one of the potato cultivars that was extensively promoted in the OR Tambo belonged to the ARC in Roodeplaat-Pretoria. Between this institute and Potato SA, there was a formal collaboration, however, ARC-ITSC was not aware of this. The directive of the new policy that recommends the public extension officers to coordinate pluralistic extension services is a welcome decision, as this is in line with some of the 
recommendations by international development organisations such as the FAO (FAO, 2016). However, in South Africa in its current state, considering the challenges of poor capacity, public extension officers will struggle to render such service (DAFF, 2016). The district office of public extension officers in OR Tambo also reported poor capacity as a challenge.

In 2018 for instance, it was said that 135 extension officers were servicing 1457382 farmers, this being far lower than the standard norms. Concerns about insufficient funding was also raised, suggesting that recruitment of new staff might be a challenge. The ARC-ITSC is of the opinion that if public extension officers were to render a coordination service, then more capacity (appropriate training) and additional resources need to be mobilised. In the study conducted by FAO (2002) in Zimbabwe, looking into the pluralistic extension model, a lack of coordination among different extension agencies was also raised as a concern. According to Rivera and Alex (2004), cited in Jadallah et al (2011), the main challenge in implementing a proper pluralistic agricultural extension mechanism is the effective coordination among various organisations, especially when competent non-public institutions are present in the country. High reliance on institutions for market access constituted another weakness. As such, 13 years into the project and farmers still relied on the ARC-ITSC for supply of certified fruit trees and other services. There was however keen interest from the farmers to be trained on nursery production. Among various extension agencies there was no common exit strategy.

\subsubsection{Opportunities}

The important attribute cited by farmers as an opportunity related to the high demand for the different crops promoted by the different extension agencies (52\% of farmers), high rainfall and good soils (12\%), and exposure (11\%). On the issue of exposure, farmers hinted that a high number of stakeholders such as universities, international organisations and government departments were visiting their projects. Literature highlights the potential for smallholder agricultural development in OR Tambo. Availability of fertile soils and high level of rainfall, in the face of undulating topography and rolling hills, discourages large-scale commercial agriculture with the results that forestry and communal farming (Muyambo, Jordaan \& Bahta, 2017) are the dominating activities. Since subsistence farming in most parts of South Africa is declining (Baiphethi \& Jacobs, 2009) due to unfavourable agrological conditions (Aliber \& Hart, 2009), inadvertently, a high number of development agents working in the area of smallholder agriculture would find OR Tambo attractive.

Favourable agro-ecological conditions enabled farmers to realise two or three cycles of production in a year. In 1999, the HVC started with 13 demonstration projects, but in 2011, some 3347 households had already planted 50454 fruit trees. A large proportion of the fruits marketed in the towns of OR Tambo were fetched from distant places such as KwaZulu-Natal, Mpumalanga and the Western Cape. Smallholder farmers had however devised means of transporting their produce to town using taxis. These taxis also carried passengers. Due to the high demand of certain types of fruits (mainly banana and oranges), there were at least five cases where farmers specialised in these commodities. The small activity for agro-processing and mobilisation of farmers into a cooperative bears a lot of potential for the HVC and this is in line with some of the provisions in the new policy. One of the strategic objectives of the new policy in section 4.1 talks for the need to "promote and implement the value chain approach". One of the farmers who received extension services from Potato SA, and operating a big plot measuring 10 hectares, had access to a pack house and her potatoes were marketed at the Fresh Produce Market in Umtata. One of the rationales for the new policy is to "broaden access to 
financial, human, physical and natural capital assets for smallholder producers and improve research outputs and access to efficient value chain-focused extension and advisory services".

\subsubsection{Threats}

Survey results show that $48 \%$ of farmers had confidence that in the next 10 years, all extension agencies will still be offering services, and $52 \%$ were not confident. Those who had no confidence mentioned the following as threats: lack of resources (funding, personnel and vehicles - 43\%), poor road conditions discouraging extension officers from visiting their projects (38\%), and conflict and politics (22\%). The ARC-ITSC reported that it was working with the local municipalities to have the issue of poor infrastructure addressed. The CDA, due to its participation in local government, was expected to address the issue of infrastructure development. Except for linking famers with authorities from the municipalities, the LIMA NGO did not have a strategy on how to deal with the challenge of poor road infrastructure. Both public extension officers and Potato SA were of the view that the issue of poor road conditions was the responsibility of municipalities.

A significant number of farmers in the HVC were elderly, with an average age of 62 years recorded amongst the 90 households. This, however, is a general problem of the world at large (Help Age International, 2014). Some of the extension agencies, such as ARC-ITSC and LIMA NGO, were of the opinion that age was not a problem as they were busy recruiting young people into the programme. It was acknowledged, however, that the current rate of commercialisation could not sustain participation of youth in the programme. Almost all of the five participating agencies were facing the problem of dwindling and waning financial support. The funding challenge also negatively affected the nature of partnerships struck, with each of the stakeholders separately pursuing partners which they knew would bring funds into the project. On the positive side, relying on donor funding encouraged hardworking, as strategies for raising capital were based on show casing good results. In most parts of South Africa, agroecological conditions are not favourable for the cultivation of fruit trees and this constitutes a threat for replication of the HVC model in its current structure to other places. As correctly stated in the new extension policy (section 5.2), "There is no single extension model or approach suited to all situations in South Africa..., the choice and combination of extension methods for implementation must be dictated by the prevailing conditions" (DAFF, 2016).

\section{CONCLUSION AND RECOMMENDATIONS}

The objective of the paper was to carry out the SWOT analyses to build insight into the important policy directives to be considered when implementing the new policy on pluralistic extension services. Based on the SWOT analyses results, the participation of multiple extension in the HVC carries opportunities for the smallholder farmers. Other important lessons include the need for effective coordination for services rendered by different agencies, and that a lack of sufficient funding threatens the sustainability of continued participation. There is a need to capacitate public extension officers to be able to manage the process for coordination. For the purpose of project sustainability, different extension agencies need to develop a common exit strategy and establish effective stakeholder forums.

\section{ACKNOWLEDGEMENT}

The authors acknowledge Ms. Rosemary Du Preez from the ITSC as she provided inputs for the design of the study and had coordinated field surveys and availed records for the project. 
Mr. Paul Olifant from the Is' Baya Development Trust assisted with the records of the farmers and provided office space for meetings. The ARC funded the research study.

\section{REFERENCES}

ALIBER, M. \& HART, T.G.B., 2009. Should subsistence agriculture be supported as a strategy to address rural food insecurity? Agrekon, 48(4):434-458.

ALTMAN, M., HART, T.G.B. \& JACOBS, P.T., 2009. Household food security status in South Africa. Agrekon, 48(4):345-361.

ANDERSON, J.R. \& FEDER, G., 2003. Rural extension. Working Paper 2976. World Bank, United States of America.

BAIPHETHI, M.N. \& JACOBS, P.T., 2009. The contribution of subsistence farming to food security in South Africa. Agrekon, 48(4):459-482.

CATLING, D., 2008. The vulnerability of small NGOs: The case of the Land Development Unit. Auckland Park: Fanele.

DE BEER, L., 2009. Development partnerships in practice: The wool industry. Paper presented to The $43^{\text {rd }}$ Conference of the South African Society for Agricultural Extension. Potchefstroom, South Africa.

DEPARTMENT OF AGRICULTURE, FORESTRY AND FISHERIES (DAFF), 2016. National policy on extension and advisory services. Available from: https://www.daff.gov.za/doaDev/topMenu/National\%20Policy.pdf

DUVEL, G., 2003. Towards an appropriate extension approach for South Africa: Recommendations. Executive Report. Pretoria, South Africa.

EWEG, M., 2009. Defining partnerships in South African agriculture. Paper presented to The $43^{\text {rd }}$ Conference of the South African Society for Agricultural Extension. Potchefstroom, South Africa.

FOOD AND AGRICULTURE ORGANIZATION OF THE UNITED NATIONS (FAO), 2001. Agricultural and rural extension worldwide: Options for institutional reform in the developing countries. Available from: http://www.fao.org/tempref/docrep/fao/004/y2709e/y2709e.pdf

FOOD AND AGRICULTURE ORGANIZATION OF THE UNITED NATIONS (FAO), 2002. Strengthening the pluralistic agricultural extension system: A Zimbabwean case study. Available from: www.fao.org/fileadmin/templates/esw/esw_new/documents/IP/4b_Strengthening the Pluralistic_Agricultural_Extension_System.pdf

FOOD AND AGRICULTURE ORGANIZATION OF THE UNITED NATIONS (FAO), 2016. New directives for inclusive pluralistic service systems. Available from: http://www.fao.org/3/a-i6103e.pdf

GEMO, H.R., STEVENS, G.B. \& CHILONDA, P., 2013. The role of pluralistic extension system in enhancing agriculture productivity in Mozambique. S. Afr. J. Agric. Ext., 41(1):59-75.

HELMS, M.M. \& NIXON, J., 2010. Exploring SWOT analysis-where are we now? A review of academic research from the last decade. J. Strategy Manag., 3(3):215-251. 
HELP AGE INTERNATIONAL, 2014. The ageing of rural populations: Evidence on older farmers in low and middle-income countries. Available from: http://www.helpage.org/silo/files/the-ageing-of-rural-populations-evidence-on-olderfarmers

INTERNATIONAL FOOD POLICY RESEARCH INSTITUTE (IFPRI), 2009. Current extension services models, what works and what does not work. Available from: https://sustainabledevelopment.un.org/content/dsd/susdevtopics/sdt_pdfs/meetings/egm 0409/presentation_NEphraim.pdf

JADALLAH, A.E., BAKAR, A.H.A. \& MOHD, J.H., 2011. The impact of decentralization and pluralism policy on agricultural extension services. J. Agric. Technol., 7(4):895-901.

JANSE VAN VUUREN, A., 2009. Successes and failures as experienced by NWK LTD with relation to partnerships in agricultural development. Paper presented to The $43^{\text {rd }}$ Conference of the South African Society for Agricultural Extension. Potchefstroom, South Africa.

JORDAAN, A.J., SISSONS, D. \& BLAKER, J., 2009. An analysis of the Mngcunube "hands on" mentorship programme for small-scale stock farmers in the Eastern Cape. Paper presented to The $43^{\text {rd }}$ Conference of the South African Society for Agricultural Extension. Potchefstroom, South Africa.

KIRSTEN, J., STANDER, R. \& HAANKUKU, C., 2010. Measuring private research and innovation in South Asia and Sub-Saharan Africa: A South Africa Country Report. Available from: citeseerx.ist.psu.edu/viewdoc/download?doi=10.1.1.423.3409\&rep=rep1\&type=pdf

LAST, C., 2006. Addressing rural poverty in South Africa: Extension services new role. Paper presented to The Conference on the Role of Extension in Rural Development and Poverty Alleviation Programmes. Berg en Dal, South Africa.

LETSOALO, E.M. \& MOLLEL, N.M., 2009. Local "is lekker": The dynamics of local partnership development between the communities, CRCE/University of Limpopo, the Limpopo Department of Agriculture and local municipalities. Paper presented to The $43^{\text {rd }}$ Conference of the South African Society for Agricultural Extension. Potchefstroom, South Africa.

LIEBENBERG, F., 2015. Agricultural advisory services in South Africa. Available from: https://tind-customer-agecon.s3.amazonaws.com/432da76e-74b8-417e-83d745c20604d4f2?response-content-disposition=inline\%3B\%20filename\%2A\%3DUTF8\%27\%27agric_advisory_services.zp64017.pdf\&response-contenttype=application\%2Fpdf\&AWSAccessKeyId=AKIAXL7W7Q3XHXDVDQYS\&Expir

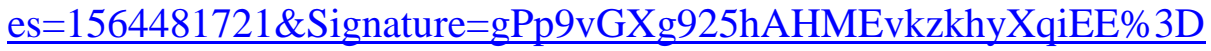

MUYAMBO, F., JORDAAN, A.J. \& BAHTA, Y.J., 2017. Assessing social vulnerability to drought in South Africa: Policy implications for drought risk reduction. Jamba, 9(1):314326.

NATIONAL TREASURY, 2017. Budget review 2017. Available from: http://www.treasury.gov.za/documents/national\%20budget/2017/review/fullbr.pdf

NGOMANE, T., THOMSON, J.S. \& RADHAKRISHNA, R.B., 2002. Public sector agricultural extension system in the Northern Province of South Africa: A system undergoing transformation. JIAEE., 9(3):31-37. 
OLADELE, O.I., LEPETU, J., SUBAIR, S.K. \& OBUH, J., 2009. SWOT analysis of extension systems in Southern African countries. JAEID., 103(4):309-320.

PADARIA, R., BAGDAS, A., VERMA, R.K., SAHOO, A.K. \& BHATTACHARYYA, S., 2013. Agriculture in India: A SWOT analysis. Indian J. Appl. Res., 3(7):4-6.

POTATO SA, 2006. Half yearly report of the activities of the transformation programme. Available from: http://www.potatoes.co.za./transformation\%20report/2006

POTATO SA, 2014. Potato industry report 2014/2015. Available from: http://www.potatoes.co.za/siteresources/documents/potato\%202014_2015

POTATO SA, 2015. Potato industry report 2015/2016. Available from: http://www.potatoes.co.za/siteresources/documents/potato2014_2015

POTATO SA, 2018. Transformation symposium. Available from: http://www.potatoes.co.za/tansformation-potato-development-programme

PROGRAMME TO SUPPORT PRO-POOR POLICY DEVELOPMENT IN SOUTH AFRICA (PSPPD), 2011. Making the case for a decentralised small-scale farmer strategy in South Africa. Available from: https://psppdknowledgerepository.org/component/jdownloads/send/17-policy-briefs/4making-the-case-for-a-decentralized-small-scale-farmer-strategy-in-southafrica?option $=$ com_jdownloads

REPUBLIC OF MOZAMBIQUE, 2007. Extension master plan 2007-2016. Available from: https://www.fanrpan.org/archive/documents/d00672/Extension_Master_Plan_2007$\underline{2016 . p d f}$

RIVERA, W.M. \& ALEX, G. 2004. The continuing role of government in pluralistic extension systems. JIAEE., 11(3):41-52.

VAN NIEKERK, J.A., STROEBEL, A., VAN ROOYEN, C.J., WHITFIELD, K.P. \& SWANEPOEL, F.C.J., 2011. Towards redressing the agricultural extension service in South Africa: Views and proposals of extension in the Eastern Cape. S. Afr. J. Agric. Ext., 39(2):57-68.

VON KODOLITSCH, Y., BERNHARDT, A.M., ROBINSON, P.N., KÖLBEL, T., REICHENSPURNER, H., DEBUS, S. \& DETTER, C., 2015. Analysis of strengths, weaknesses, opportunities and threats as a tool for translating evidence into individualized medical strategies (I-SWOT). Aorta, 3(3):98-107.

WORLD BANK, 2015. SWOT analysis for agricultural banking. Available from: https://www.agrifinfacility.org/sites/agrifin/files/1516527_AgriFin_Knowledge_Notes $\underline{\text { SWOT.PDF }}$

YOUNT, W.R., 2006. Research design and statistical analysis for Christian ministry. Fort Worth: WR Yount. 
